$\begin{array}{ll}\text { Volume } & : 05 \\ \text { Nomor } & : 03 \\ \text { Bulan } & : \text { September } \\ \text { Tahun } & : 2019 \\ \text { Http } & : \text { //ejurnal.pps.ung.ac.id/index.php/AKSARA/index }\end{array}$

\title{
DAMPAK TUNJANGAN PROFESI TERHADAP MOTIVASI KERJA GURU SMA DI KOTA GORONTALO PROVINSI GORONTALO.
}

\author{
Mohammad Fadli A. Himran, Heldy Vanni Alam \\ Fakultas Ekonomi Universitas Negeri Gorontalo \\ mohfadlihimran@gmail.com
}

Received: 02 Juni 2019; Revised: 19 Juli 2019; Accepted: 25 Agustus 2019

\begin{abstract}
ABSTRAK
Penelitian ini bertujuan untuk mengetahui dampak tunjangan profesi terhadap motivasi kerja guru SMA Negeri di Kota Gorontalo Provinsi Gorontalo.Jenis penelitian survei dengan metode kuantitatif. Populasi penelitian ini adalah guru PNS SMA Negeri di Kota Gorontalo yang berjumlah 215 orang.Jumlah sampel 140 orang guru yang diambil dengan menggunakan Rumus Slovin.Teknik pengumpulan data menggunakan kuesioner dan teknik analisis data menggunakan analisis regresi linear sederhana. Berdasarkan hasil penelitian dan analisis data, maka diperoleh persamaan regresi $\hat{Y}=19,668+0,627 X$ yang berarti bahwa setiap terjadi perubahan pada satu-satuan variabel tunjangan profesi, maka akan diikuti oleh perubahan sebesar 0,627 atau 62,7\% satuan pada varibel motivasi kerja guru.Hasil penelitian menunjukan pula bahwa tunjangan profesi memiliki dampak positif terhadap meningkatnya motivasi kerja guru SMA Negeri di Kota Gorontalosebesar 36,2\%.Dengan demikian, hipotesis penelitian dapat diterima.
\end{abstract}

Kata kunci: Tunjangan Profesi dan Motivasi Kerja Guru.

\section{PENDAHULUAN}

Motivasi merupakan dorongan individu untuk melakukan tindakan karena mereka ingin melakukannya. Apabila individu termotivasi, mereka akan membuat pilihan yang positif untuk melakukan sesuatu, karena dapat memuaskan keinginan mereka. Pada dasarnya motivasi dapat memacu guru untuk bekerja keras sehingga dapat mencapai tujuan mereka. Hal ini akan meningkatkan produkitivitas kerja guru sehingga berpengaruh pada pencapaian tujuan lembaga pendidikan. Motivasi berasal dari kata motif (motive), yang berarti dorongan.Menurut Bangun (2012:312): "Motivasi adalah suatu kondisi yang mendorong atau menjadi sebab seseorang untuk dapat melaksanakan tugas-tugas sesuai dengan fungsinya dalam organisasi". Sedangkan menurut Rivai (2011:837): "Motivasi adalah serangkaian sikap dan nilai-nilai yang mempengaruhi individu untuk mencapai hal yang spesifik sesuai dengan tujuan individu. Sikap dan nilai tersebut merupakan suatu yang invisible yang memberikan kekuatan untuk mendorong individu bertingkah laku dalam mencapai tujuan". Dorongan tersebut terdiri dari dua komponen, yaitu : arah perilaku (kerja untuk mencapai tujuan), dan kekuatan perilaku (seberapa kuat usaha individu dalam bekerja).

Ada berbagai macam motivasi dalam diri manusia yang tergantung kepada kebutuhan mana yang akan diutamakan. Apabila kebutuhan utama tersebut telah terpenuhi maka akan timbul kebutuhan lain dari kebutuhan yang sebelumnya. Hal ini akan berlanjut terus sampai kepada kebutuhan yang belum pernah dimiliki oleh orang lain. Artinya, manusia dapat saja menggunakan orang lain sebagai patokan terhadap suatu kebutuhan untuk memotivasi mencapai hal yang sama tetapi dapat juga untuk mencapai hal-hal lain karena berbeda terhadap sesuatu yang diinginkan. Motivasi dalam hal ini lebih menitikberatkan pada gairah kerja seorang guru, agar mau dan mampu bekerja keras dengan menyumbangkan segenap 


$\begin{array}{ll}\text { Volume } & : 05 \\ \text { Nomor } & : 03 \\ \text { Bulan } & : \text { September } \\ \text { Tahun } & : 2019 \\ \text { Http } & : / / \text { ejurnal.pps.ung.ac.id/index.php/AKSARA/index }\end{array}$

kemampuan, pikiran, dan keterampilan yang dimiliki untuk mewujudkan tujuan yang diharapkan. Guru juga harus memiliki cadangan energi potensial, dimana energi tersebut akan dilepaskan atau digunakan tergantung pada kekuatan dorongan motivasinya, serta situasi dan peluang yang tersedia (Sungkono dkk, 2011: 549). Motivasi kepada seorang guru sangat diperlukan untuk meningkatkan kinerjanya.Motivasi harus diciptakan sebaik-baiknya supaya moral kerja, dedikasi dan kecintaan serta kedisiplinan para guru meningkat.

Beberapa tahun terakhir ini, profesi guru seolah-olah menjadi profesi yang didambakan oleh banyak orang. Terlebih setelah tahun pertama digulirkannya sertifikasi guru pada tahun 2007 yang merupakan implementasi dari Undang-Undang Nomor 14 Tahun 2005 tentang guru dan dosen, guru benar-benar menjadi profesi yang banyak diimpikan. Selain profesi ini adalah hal yang mulia, ternyata perhatian pemerintah dalam bidang pendidikan khususnya pemberian tunjangan profesi pendidik membuat banyak yang tergiur dengan profesi ini.Pada tahun 2015 jumlah guru SMA yang ada di Kota Gorontalo yakni berjumlah 215 orang.Dari 215 orang guru yang tersertifikasi yakni bejumlah 179 orang, sedangkan jumlah guru yang belum tersertifikasi yakni 36 orang. Hal tersebut menunjukan bahwa 83,26\% guru SMA yang ada di Kota Gorontalo yang sudah tersertifikasi dan 16,74\% guru SMA yang ada di Kota Gorontalo yang belum tersertifikasi.

Fenomena yang terlihat pada Guru SMA di Kota Gorontalo bahwa sebagian besar mereka menjalankan tugas rutinitas mengajar. Sedikit dari jumlah tersebut yang berpikir untuk meningkatkan kompetensi, kemampuan dan kreativitasnyabaik untuk kepentingan pembelajaran maupun untuk diri sendiri yang merupakan bagian dari komunitas masyarakat.Begitu banyak kegiatan dalam rangka peningkatan kompetensi dan professional guru yang digelar baik dalam bentuk seminar, workshop, dan bentuk kegiatan lainnya, namun tidak semua guru memiliki kemauan untuk ikut serta dalam forum-forum ilmiah tersebut.Terkecuali kegiatan yang dilaksanakan oleh pihak sekolah dan pihak diknas. Di samping itu juga data yang diperoleh bahwa dari 215 orang guru SMA hanya 38 orang guru yang telah melanjutkan pendidikannya ke jenjang Magister dan Doktor, masing-masing 35 Magister dan 3 Doktor. Mereka cenderung beranggapan bahwa lebih baik menyekolahkan anak-anak mereka dibandingkan diri mereka.Hal ini tentunya perlu dicari akar permasalahannya.

Salah satu hal yang diprediksi dapat meningkatkan motivasi kerja seorang guru dalam suatu lembaga pendidikan adalah adanya kompensasi yang dalam hal ini yakni tunjangan profesi.Hal ini diperkuat dengan hasil penelitian Murwati (2013) yang menunjukkan bahwa sertifikasi profesi guru berpengaruh terhadap motivasi kerjanya, yang ditunjukkan oleh $t$ hitung $(10,664)>t$ table $(1,664)$.Hal tersebut merupakan suatu dorongan untuk bisa meningkatkan motivasi di berbagai aktivitas yang harus dilakoni oleh guru di lingkungan tempat dia bertugas.Apresiasi pemerintah terhadap kinerja guru dapat dilihat dari keluarnya Undang-Undang Nomor 14 Tahun 2005 tentang Guru dan Dosen dimana pada Pasal 16 ayat (2) dinyatakan bahwa guru yang telah memiliki sertikat pendidik dan memenuhi persyaratan lainnya berhak mendapatkan tunjangan profesi yang besarnya setara dengan satu kali gaji pokok dan dalam ayat (3) menyatakan tunjangan profesi sebagaimana dimaksud dialokasikan dalam Anggaran Pendapatan dan Belanja Negara (APBN) dan/atau Anggaran Pendapatan dan Belanja Daerah (APBD). Olehnya itu, penelitian ini dilakukan untuk mengetahui pengaruh tunjangan profesi terhadap motivasi kerja guru SMA Negeri di Kota Gorontalo. 


$\begin{array}{ll}\text { Volume } & : 05 \\ \text { Nomor } & : 03 \\ \text { Bulan } & : \text { September } \\ \text { Tahun } & : 2019 \\ \text { Http } & : / / \text { ejurnal.pps.ung.ac.id/index.php/AKSARA/index }\end{array}$

\section{TINJAUAN PUSTAKA}

\section{Tunjangan Profesi}

Menurut Depdiknas (2015:6):"Tunjangan profesi pendidik adalah salah satu bentuk peningkatan kesejahteraan yang diberikan kepada guru yang besarnya setara dengat 1 (satu) kali gaji pokok bagi guru yang diangkat oleh satuan pendidikan yang diselenggaraan oleh pemerintah atau pemerintah daerah pada tingkat, masa kerja, dan kualifikasi yang sama. Dalam melaksanakan tugas keprofesionalan, guru berhak memperoleh penghasilan di atas kebutuhan hidup minimum sebagaimana dimaksud dalam Undang-Undang Nomor 14 Tahun 2005 Pasal 14 ayat (1) huruf (a) yang berarti pendapatan yang cukup untuk memenuhi kebutuhan hidup guru dan keluarganya secara wajar, baik sandang, pangan, papan, kesehatan, pendidikan, rekreasi, maupun jaminan hari tua yang terkait dengan tugasnya sebagai guru yang ditetapkan dengan prinsip penghargaan atas dasar prestasi."

Tunjangan profesi dimaksudkan untuk meningkatkan mutu guru PNS Jenjang Pendidikan Menengah di bawah binaan provinsi dan guru bukan PNS Jenjang Pendidikan Menengah, pengawas satuan pendidikan. Sebagai penghargaan atas profesionalitas untuk mewujudkan amanat Undang-Undang Guru dan Dosen antara lain mengangkat martabat guru, meningkatkan kompetensi guru, memajukan profesi guru, meningkatkan mutu pembelajaran, dan meningkatkan pelayanan pendidikan yang bermutu. Tunjangan profesi yang dibayarkan melalui DIPA tahun 2015 Direktorat Pembinaan PTK Menengah adalah tunjangan yang diberikan kepada guru bukan PNS Jenjang Pendidikan Menengah, guru PNS Jenjang Pendidikan Menengah di bawah binaan provinsi, dan pengawas satuan pendidikan di bawah binaan Provinsi yang telah memiliki sertifikat pendidik dan memenuhi persyaratan lainnya.

\section{Dasar Hukum Sertifikasi Guru}

MenurutDirjen PMPTK DepartemenPendidikan Nasional tahun2007, dasar hukum sertifikasi profesi guru adalah sebagai berikut:

1. Undang-UndangRepublik IndonesiaNomor 20 tahun 2003 Tentang Sistem Pendidikan Nasional:

a.Pasal 42 ayat (1), Pendidik harus memiliki kualifikasi minimum dan sertifikasi sesuai dengan jenjang kewenangan mengajar, sehat jasmani dan rohani, serta memiliki kemampuan untuk mewujudkan tujuan pendidikan nasional.

b.Pasal 43 ayat (2), Sertifikasi pendidik diselenggarakan oleh perguruan tinggi yang memiliki program pengadaantenaga kependidikan yang terakreditasi.

2. Undang-UndangRepublik Indonesia Nomor 14 Tahun 2005 tentang Guru dandosen:

a.Pasal 8,Guruwajibmemiliki kualifikasi akademik, kompetensi, sertifikat pendidik, sehat jasmani dan rohani, serta memiliki kemampuan untuk mewujudkan tujuan pendidikan nasional.

b.Pasal 11 ayat (1), Sertifikat pendidik sebagaimana dimaksud dalam pasal 8 diberikan kepada guru yang telah memenuhipersyaratan, ayat (2)Sertifikasi pendidik diselenggarakan oleh perguruan tinggi yang memiliki program pengadaan tenaga kependidikan yang terakreditasi dan ditetapkan oleh Pemerintah, ayat (3) Sertifikasi pendidik dilaksanakan secara objektif, transparan, dan akuntabel, ayat (4) Ketentuan lebih lanjut mengenai sertifikasi pendidik sebagaimana dimaksud pada ayat (2) dan ayat (3) diatur dengan Peraturan Pemerintah.

3. Peraturan Menteri Pendidikan Nasional nomor 16 tahun 2007 tentang Standar Kualifikasi dan Kompetensi Guru.

4. Peraturan Menteri Pendidikan Nasional nomor 18 tahun 2007 tentangSertifikasi bagi Guru dalam jabatan. 


$\begin{array}{ll}\text { Volume } & : 05 \\ \text { Nomor } & : 03 \\ \text { Bulan } & : \text { September } \\ \text { Tahun } & : 2019 \\ \text { Http } & : \text { //ejurnal.pps.ung.ac.id/index.php/AKSARA/index }\end{array}$

\section{Motivasi Kerja}

Robbins dan Judge (2012 : 202) mendefinisikan motivasi sebagai bentuk proses yang mencakup intensitas, arah, dan ketekunan seorang individu dalam upayanya mencapai sasaran. Dalam hubungannya dengan dunia pekerjaan, yang dimaksud sasaran tentunya yang berkaitan dengan perilaku dalam bekerja..Sedarmayanti (2013 : 66) mendefinisikan pula bahwa: "Motivasi dapat diartikan sebagai suatu daya pendorong (driving force) yang menyebabkan orang berbuat sesuatu atau yang diperbuat karena takut akan sesuatu. Misalnya ingin naik pangkat atau naik gaji, maka perbuatannya akan menunjang pencapaian keinginan tersebut. Yang menjadi pendorong dalam hal tersebut adalah bermacam-macam faktor diantaranya faktor ingin lebih terpandang di antara rekan kerja atau lingkungan dan kebutuhannya untuk berprestasi."

SelanjutnyaAlice (2004) mengatakan bahwa motivasi kerja guru adalah faktor-faktor yang mendorong seorangguru untuk melakukan pekerjaannya, secara lebih bersemangat sehingga akan memperoleh prestasi yang lebih baik.Motivasi kerja dapat didefinisikan pula sebagai suatu ketrampilan dalam memadukan kepentingan guru dengan organisasi sehingga guru dapat terpuaskan bersama dengan tercapainya sasaran-sasaran organisasi.Untuk menggerakkan manusia agar sesuai dengan yang dikehendaki organisasi, maka haruslah dipahami motivasi manusia yang bekerja didalam organisasi tersebut, karena motivasi inilah yang menekankan perilaku manusia yang bekerja.Secara implisit, motivasi kerja tampak melalui:

a. Tanggung jawab dalam melakukan kerja

b. Prestasi yang dicapainya

c. Pengembangan diri, serta

d. Kemandirian dalam bertindak

\section{Alat-Alat Motivasi}

Hasibuan (2005), mengemukakan bahwa alat-alat motivasi dapat berupa:

1. Materiil insentif; Yaitu motivasi yang diberikan itu berupa uang dan atau barang yang mempunyai nilai pasar, dengan kata lain insentif

2. tersebut memberikan nilai ekonomis.Contoh : uang, kendaraan, rumah.

3. Non Materiil Insentif.Yaitu alat motivasi yang diberikan itu berupa barang/ benda yang tidak ternilai, jadi hanya memberikan kebanggaan ataukepuasan rohani saja.

4. Contoh: medali, piagam, bintang jasa.

5. Kombinasi Materiil dan Nonmateriil

6. Insentif; Yaitu alat motivasi yang diberikan itu berupa materiil (uang dan barang) dan nonmaterial (medali/piagam), jadi memenuhi kebutuhan ekonomis dankepuasan/ kebanggan rohani.

\section{Hubungan Tunjangan Profesi dan Motivasi Kerja Guru}

Kunandar (2009) menyatakan bahwa sertifikasi profesi guru adalah proses untuk memberikan sertifikat kepada guru yang telahmemenuhi standar kualifikasi dan standar kompetensi. Berdasarkan pengertian tersebut dapat diketahui bahwa guru yang telah lulus program sertifikasi profesi akan mendapatkan sertifikat pendidik dimana sertifikat tersebutmerupakan bukti bahwa guru telah memenuhi standar kualifikasi dan kompetensi sebagai seorang guru. Selain mendapatkan sertifikat pendidik, guru yang telah lulus sertifikasi juga akan mendapatkan tunjangan profesi sebesarsatu kali gaji pokok. Salah satu alat motivasi yang dapat digunakan untuk memotivasi seseorang adalah alat motivasi yang berupa materiil (uang dan barang) dan nonmateriil(medali/piagam). Dengan demikian, dengan adanya 


$$
\begin{array}{ll}
\text { Volume } & : 05 \\
\text { Nomor } & : 03 \\
\text { Bulan } & : \text { September } \\
\text { Tahun } & : 2019 \\
\text { Http } & : \text { //ejurnal.pps.ung.ac.id/index.php/AKSARA/index }
\end{array}
$$

pemberian sertifikat profesi disertai tunjangan profesi bagi guru yang telah lulusprogram sertifikasiguru, maka akan meningkatkan motivasi kerja pada diri guru tersebut. Sehingga dapat dikatakan bahwa pemberian tunjangan profesi oleh pemerintah akan berpengaruh terhadap motivasi kerja guru.

\section{METODE PENELITIAN}

Jenis penelitian ini adalah penelitian survey dengan menggunakan metode kuantitatif. Populasi dalam penelitian ini adalah guru SMA Negeri se- Kota Gorontalo yang berjumlah 215 orang.Dengan menggunakan formula Slovin, maka ditetapkan sampel penelitian sebanyak 140 orang.Teknik sampling yang digunakan dalam penelitian ini yakni simple random sampling. Data yang dikumpulkan melalui penyebaran instrumen berupa angket dengan pemberian obot skor 1-5.Angket.Sebelumnya instrumen angket diuji validitas dan reliabilitasnyakepada responden di luar sampel agar benar-benar valid dan reliable. Selanjutnya data yang dihasilkan melalui penyebaran angket ke responden utama dianalisis menggunakan regresi linier sederhanadengan bantuan program SPSS.

\section{HASIL PENELITIAN DAN PEMBAHASAN}

Salah satu asumsi yang harus dipenuhi dalam melakukan analisis regresi linear sederhana adalah data variable dependen (terikat) harus berasal dari populasi yang berdistribusi normal. Untuk itu sebelum diolah lebih lanjut, dilakukan pengujian asumsi normalitas.Pengujian dilakukan dengan menggunakan bantuan SPSS dan diperoleh hasil sebagaimana tabel berikut.

Tabel 1. Hasil Uji Kolmogorov-Smirnov One-Sample Kolmogorov-Smirnov Test

\begin{tabular}{|c|c|c|c|c|}
\hline & & $\begin{array}{l}\text { Tunjangan } \\
\text { Profesi }\end{array}$ & $\begin{array}{l}\text { Motivasi } \\
\text { Kerja }\end{array}$ & $\begin{array}{l}\text { Unstandardized } \\
\text { Residual }\end{array}$ \\
\hline $\mathrm{N}$ & & 140 & 140 & 140 \\
\hline Normal Parameters ${ }^{\mathrm{a}, \mathrm{b}}$ & $\begin{array}{l}\text { Mean } \\
\text { Std. } \\
\text { Deviation }\end{array}$ & $\begin{array}{l}50.3500 \\
7.30577\end{array}$ & $\begin{array}{l}51.2556 \\
7.61772\end{array}$ & $\begin{array}{l}.0000000 \\
6.08457019\end{array}$ \\
\hline $\begin{array}{ll}\text { Most } & \text { Extreme } \\
\text { Differences } & \end{array}$ & $\begin{array}{l}\text { Absolute } \\
\text { Positive } \\
\text { Negative }\end{array}$ & $\begin{array}{l}.069 \\
.053 \\
-.069\end{array}$ & $\begin{array}{l}.099 \\
.041 \\
-.099\end{array}$ & $\begin{array}{l}.094 \\
.056 \\
-.094\end{array}$ \\
\hline $\begin{array}{l}\text { Kolmogorov-Smirnov Z } \\
\text { Asymp. Sig. (2-tailed) }\end{array}$ & & $\begin{array}{l}.817 \\
.517\end{array}$ & $\begin{array}{l}1.174 \\
.127\end{array}$ & $\begin{array}{l}1.115 \\
.166\end{array}$ \\
\hline
\end{tabular}

Sumber : Data primer diolah dalam Statistik SPSS 21, 2016

Setelah dilakukan uji asumsi normalitas dan ternyata dipenuhi, tahap selanjutnya dilakukan pemodelan data dengan menggunakan analisis regresi sederhana. Hasil analisis dengan SPSS ditampilkan sebagai berikut : 


$\begin{array}{ll}\text { Volume } & : 05 \\ \text { Nomor } & : 03 \\ \text { Bulan } & : \text { September } \\ \text { Tahun } & : 2019 \\ \text { Http } & : \text { //ejurnal.pps.ung.ac.id/index.php/AKSARA/index }\end{array}$

Tabel 2. Hasil AnalsisSzzec Regresi Linier Sederhana

Coefficients $^{\mathrm{a}}$

\begin{tabular}{|c|c|c|c|c|c|c|}
\hline \multirow[b]{2}{*}{ Model } & & \multicolumn{2}{|c|}{$\begin{array}{l}\text { Unstandardized } \\
\text { Coefficients }\end{array}$} & \multirow{2}{*}{\begin{tabular}{|l} 
Standardized \\
Coefficients \\
Beta \\
\end{tabular}} & \multirow[b]{2}{*}{$\mathrm{T}$} & \multirow[b]{2}{*}{ Sig. } \\
\hline & & B & Std. Error & & & \\
\hline & (Constant) & 19.668 & 3.607 & & 5.453 & .000 \\
\hline 1 & $\begin{array}{l}\text { Tunjangan } \\
\text { Profesi } \\
\text { Pendidik }\end{array}$ & .627 & .071 & .602 & 8.849 & .000 \\
\hline
\end{tabular}

Sumber : Data primer diolah dalam Statistik SPSS 21, 2016

Berdasarkan tabel 2 di atas diperoleh persamaan sebagai berikut:

Hasil Uji Hipotesis $\quad \hat{Y}=19.668+0.627 X$

Pengujian Secara Parsial (t-test)

Tabel 3. Pengujian Hipotesis Secara Parsial(t-test)

Coefficients $^{\mathrm{a}}$

\begin{tabular}{|c|c|c|c|c|c|c|}
\hline \multirow[b]{2}{*}{ Model } & & \multicolumn{2}{|c|}{$\begin{array}{l}\text { Unstandardized } \\
\text { Coefficients }\end{array}$} & \multirow{2}{*}{$\begin{array}{l}\text { Standardized } \\
\text { Coefficients } \\
\text { Beta } \\
\end{array}$} & \multirow[b]{2}{*}{$\mathrm{T}$} & \multirow[b]{2}{*}{ Sig. } \\
\hline & & B & Std. Error & & & \\
\hline & (Constant) & 19.668 & 3.607 & & 5.453 & .000 \\
\hline 1 & $\begin{array}{l}\text { Tunjangan } \\
\text { Profesi } \\
\text { Pendidik }\end{array}$ & .627 & .071 & .602 & 8.849 & .000 \\
\hline
\end{tabular}

Data primer diolah dalam Statistik SPSS 21, 2016

Dari hasil perhitungan diperoleh nilai $t_{\text {hitung }}$ untuk variabel Tunjangan Profesi sebesar 8,849 dengan $P_{\text {value }}$ sebesar 0,000 . Dengan menggunakan batas signifikan $\alpha=0,05$ didapat $t_{\text {tabel }}$ sebesar 1,6559.Dari hasil tersebut maka kriteria pengujian yaitu $t_{\text {hitung }}>t_{\text {tabel }}$ atau $P_{\text {value }}<\alpha$ yang artinya $\mathrm{H} 0$ ditolak dan $\mathrm{H} 1$ diterima. Dengan demikian dapat disimpulkan bahwa tunjangan profesi berpengaruh terhadap motivasi kerja guru SMA Negeri di Kota Gorontalo.

Berdasarkan hasil estimasi model persamaan regresi yang telah dilakukan diperoleh nilai koefisien determinasi $\mathrm{R}^{2}$ sebesar 0,602 atau mendekati satu artinya terdapat hubungan yang agak kuat. Selanjutnya diperoleh nilai $\mathrm{R}$-Square atau koefisiensi determinasi $\mathrm{R}^{2}$ menunjukan besarnya kontribusi sebesar 0,362. Nilai ini berarti bahwa sebesar 36,2\% variabilitas mengenai variabel dependen (motivasi kerja guru SMA Negeri di Kota Gorontalo) dapat diterangkan oleh variabel independen (tunjangan profesi), sedangkan sisanya sebesar 63,8\% dipengaruhi oleh variabel lain yang tidak terdapat pada model. 


$\begin{array}{ll}\text { Volume } & : 05 \\ \text { Nomor } & : 03 \\ \text { Bulan } & : \text { September } \\ \text { Tahun } & : 2019 \\ \text { Http } & : \text { //ejurnal.pps.ung.ac.id/index.php/AKSARA/index }\end{array}$

\section{PENUTUP}

Kompensasi merupakan salah satu hal yang dipelajari dalam bidang ilmu MSDM. Menurut Bangun (2012:255): "Kompensasi merupakan imbalan yang dibayarkan kepada karyawan atas jasa yang mereka sumbangkan pada pekerjaannya." Selanjutnya pendapat Rivai (2011: 741) yang mengemukakan bahwa : "kompensasi merupakan sesuatu yang diterima karyawan sebagai pengganti kontribusi jasa mereka pada perusahaan."Pemberian kompensasi merupakan salah satu pelaksanaan fungsi MSDM yang berhubungan dengan semua jenis pemberian penghargaan individual sebagai pertukaran dalam melakukan tugas keorganisasian.Kompensasi merupakan biaya utama atas keahlian atau pekerjaan dan kesetiaan dalam bisnis perusahaan pada abad ke-21 ini.Kompensasi menjadi alasan utama mengapa kebanyakan orang mencari pekerjaan.

Kompensasi dalam dunia pendidikan dikenal dengan istilah tunjangan profesi pendidik. Menurut Depdiknas (2015:6) Tunjangan profesi pendidik adalah salah satu bentuk peningkatan kesejahteraan yang diberikan kepada guru yang besarnya setara dengat 1 (satu) kali gaji pokok bagi guru yang diangkat oleh satuan pendidik yang diselenggaraan oleh pemerintah atau pemerintah daerah pada tingkat, masa kerja, dan kualifikasi yang sama. Dalam melaksanakan tugas keprofesionalan, guru berhak memperoleh penghasilan di atas kebutuhan hidup minimum sebagaimana dimaksud dalam Undang-Undang Nomor 14 Tahun 2005 Pasal 14 ayat (1) huruf (a) yang berarti pendapatan yang cukup untuk memenuhi kebutuhan hidup guru dan keluarganya secara wajar, baik sandang, pangan, papan, kesehatan, pendidikan, rekreasi, maupun jaminan hari tua yang terkait dengan tugasnya sebagai guru yang ditetapkan dengan prinsip penghargaan atas dasar prestasi.

Tunjangan profesi dimaksudkan untuk peningkatan mutu guru PNS Jenjang Pendidikan Menengah di bawah binaan provinsi dan guru bukan PNS Jenjang Pendidikan Menengah, pengawas satuan pendidikan. Pendidikan Menengah di bawah binaan Provinsi sebagai penghargaan atas profesionalitas yang telah ditunjukkan guna mewujudkan amanat UndangUndang Guru dan Dosen antara lain mengangkat martabat guru, meningkatkan kompetensi guru, memajukan profesi guru, meningkatkan mutu pembelajaran, dan meningkatkan pelayanan pendidikan yang bermutu.Dengan adanya tunjangan profesi pendidik, guru diharapkan memiliki motivasi kerja yang tinggi sehingga mampu menciptakan prestasi yang membanggakan.Di samping itu juga tunjangan profesi pendidik mampu mendorong kreativitas dan kemampuan guru dalam menjalankan tugas pokoknya yang ditunjukkan dengan memiliki keempat kemampuan, yaitu kemampuan merencanakan pembelajaran, kemampuan melaksanakan pembelajaran, kemampuan melakukan evaluasi dan kemampuan mengembangkan peserta didik untuk mengaktualisasikan berbagai potensinya.Berdasarkan fakta dilapangan, motivasi kerja guru tidak akan begitu saja meningkat apabila tidak ada sejumlah tunjanganyang mendukung. Semangat guru mengikuti sertifikasi bukan hanya semata untuk mendapatkan pengakuan keprofesionalnya saja, tetapi juga untuk mendapatkan sejumlah tunjangan profesi pendidik.Olehnya itu, hipotesis penelitian dapat diterima karena tunjangan profesi pendidik mampu memberikan dampak terhadap motivasi kerja guru SMA Negeri di Kota Gorontalo. 


$\begin{array}{ll}\text { Volume } & : 05 \\ \text { Nomor } & : 03 \\ \text { Bulan } & : \text { September } \\ \text { Tahun } & : 2019 \\ \text { Http } & : \text { //ejurnal.pps.ung.ac.id/index.php/AKSARA/index }\end{array}$

DAFTAR PUSTAKA

Sugiyono. 2012. Metode Penelitian Pendidikan, Pendekatan Kuantitatif, Kualittatif, dan R\&D. Bandung : Alfabeta

Sumantri Mulyani, 2009. Perkembangan Peserta Didik, Jakarta: Universitas Terbuka

Supriatna, Nana. Dkk. 2002. Bahan Belajar Mandiri Pendidikan IPS di SD. Bandung: IKIP Bandung Press.

Suprijono, Agus. 2010. Cooperative Learning. Yogyakarta: Pustaka Belajar.

Suyatno. 2010. Menjelajah Pembelajaran Inovatif. Sidoarjo: Masmedia Buana Pustaka.

Tim Penyusun. 2013. Pedoman Penulisan Skripsi. Palembang : FKIP Universitas. PGRI

Trianto. 2010. Mendesain Model Pembelajaran Inovatif-Progresif. Jakarta: Perenada Media Grup.

., 2011. Model-model pembelajaran inovatif berorientasi konstruktivitis. Jakarta: Prestasi Pustaka.

Uno B. Hamzah, dkk, 2008. Pengantar Teori Belajar dan Pembelajaran, Gorontalo: BMT Nurul Jannah

Uzer, Moh. Usman, 2007. Menjadi Guru Profesional, Jakarta: Rosda Karya

Wahab Azis Abdul, 2008. Konsep Dasar IPS. Jakarta: Universitas Terbuka.

Wena, Made 2009. Strategi Pembelajaran Inovatif Kontenporer. Jakarta : Bumi Aksara 